\title{
Evaluation of Introduced Grass Pea Entries and Effect of Increased Levels of Nitrogen Fertilization on Productivity under Irrigated Conditions in Egypt
}

Ahmed M. El-Sayed ${ }^{1}$, Ali I. Nawar ${ }^{1}$ and Mahmoud M.Zeid ${ }^{1 *}$

\begin{abstract}
Grass pea (Lathyrus sativus L.) is a legume that has recently gained attention in many countries for its good protein content and its tolerance to harsh conditions. The idea of using stored grass pea winter produced seeds and hay to compensate for the low protein feed from grasses in the summer season in Egypt has been suggested decades ago. However, production of the crop under local conditions needs to be evaluated. This study aimed to evaluate performance of introduced grass pea entries under local conditions and to investigate the effect of increased levels of nitrogen fertilization on growth and productivity of a selected set of entries. Ten entries were grown in a randomized complete block design with three replicates to evaluate their production under irrigated conditions in two successive growing seasons in Alexandria, Egypt. The highest recorded seed yield and biological yield values were 0.65 and 2.69 t/ha, respectively. A second field trial was also set using the same statistical design to investigate the effect of nitrogen fertilization (96, 144 and $192 \mathrm{~kg} \mathrm{~N} / \mathrm{ha}$ ) on growth and productivity of five check entries. Results indicated an average increase in biological yield from 5.2 to $6.3 \mathrm{t} / \mathrm{ha}$ and in seed yield from 0.77 to $0.98 \mathrm{t} / \mathrm{ha}$ with increasing nitrogen fertilization from 96 to $192 \mathrm{~kg} \mathrm{~N} / \mathrm{ha}$. It could be concluded that grass pea responded positively to the increase in nitrogen fertilization levels, however, the studied entries were not best suited to our local conditions. Productivity of the screened entries was modest compared with that of other countries with much lower inputs. Thus, screening a larger number of entries under varying environments is necessary if higher production levels under less favorable conditions are to be achieved.
\end{abstract}

Key words: (Lathyrus sativus L.), soil cover, seed yield, biological yield

\section{INTRODUCTION}

Agriculture in Egypt depends basically on water provided by the river Nile (82.6\%), mainly through surface irrigation. Rain on the other hand, representing $0.8 \%$, is unequally distributed and reaches only limited areas and amounts to about $200 \mathrm{~mm}$ annually (ElNahrawy 2011). The area devoted to forage crops in Egypt has been on the decline; from $27.3 \%$ of the cultivated area in the 1980 's to $16.9 \%$ in 2009 . Berseem clover, the main forage crop in Egypt, covers 1.3 million hectares mostly in the Nile Valley and its Delta in the winter season. A critical shortage in forages in the summer season prevails, in contrast to the surplus of berseem clover in the winter season. While berseem clover provides the protein content required by animals during the winter season (October to May), a tremendous drop in this content occurs in the six months to follow where animals depend mainly on straw from grasses, poor in protein content (El-Nahrawy 2011).

Grass pea (Lathyrus sativus L.), a mono cut forage crop, was suggested by Abd El-Moneim and Ryan (2004), as a N-fixing feed legume, that can be one remedy to the seasonal feed shortage, and could also help to alleviate grazing pressures on rangelands and improve soil productivity. Reports on its tolerance to harsh growing conditions (drought, water logging and salinity) and its resistance to many pests compared to other legumes has drawn attention to the crop in China, Canada and Australia as a good source of calories and protein in poor soils of arid and semiarid environments. Hanbury et al. (2000) showed that the protein content in seeds of grass pea was around $27 \%$. Because of its good protein content and its tolerance to harsh conditions, Petritz et al. (1980), suggested growing grass pea on low quality soils to provide seeds that are a good and cheap protein source to supplement straws consumed in the summer season. This suggestion might be applicable in Egypt, provided that good yielding grass pea entries are identified under local conditions.

Research on mineral fertilization of grass pea for improvement of forage and seed productivity has focused mainly on phosphorous fertilization in areas with low phosphorus availability or retention capacity. Phosphorus has proven to improve yield only in soils with available $\mathrm{P}_{2} \mathrm{O}_{5}<10 \mathrm{mg} / \mathrm{kg}$ (Montenegro and Mera, 2009 and Larbi et al., 2010). Furthermore, phosphorus showed synergistic effects on Rhizobium activity leading to increase in its nitrogen fixing ability on grass pea as shown by Sarkar et al., 2003. In that study, the effect of foliar spray of $\mathrm{Ca}\left(\mathrm{NO}_{3}\right)_{2}$ and $\mathrm{KNO}_{3}$ on grass pea grown in rice fallows in India was studied by Sarkar and Malik (2001). An increase in seed yield in that study was attributed mainly to the positive effects of $\mathrm{N}$ on photosynthetic activity that lead to improved pod filling.

To study the possibility of utilizing grass pea as a plant source for animal feed in the form of seed protein and hay, this study was conducted to investigate the

${ }^{1}$ Department of Crop Science, Faculty of Agriculture, Alexandria

University, Alexandria, Egypt.

* Corresponding author's email: mahmoud.zeid@alexu.edu.eg

Received May, 15, 2017, Accepted June 19, 2017 
performance and productivity of a set of ten introduced grass pea entries under local conditions in Alexandria and also to investigate the effect of increased levels of nitrogen fertilization on growth and productivity of a second set of five other selected entries.

\section{MATERIALS AND METHODS}

Two experiments were conducted in parallel in the two growing seasons of 2012/2013 (S1) and 2013/2014 (S2) at the agricultural research station, Faculty of Agriculture, Alexandria University. In the first experiment, 10 grass pea (Lathyrus sativus L.) entries representing three different yield trials designed by ICARDA, namely: early maturity, high biomass and low B-ODAP (Oxalydiaminopropionic acid) were evaluated for their productivity under local conditions (Table 1).

Table 1. Entries evaluated for their growth and productivity in the seasons $2012 / 2013$ and $2013 / 2014$ under one level of nitrogen fertilization (1-10) and three levels of nitrogen fertilization (Check 1-5)

\begin{tabular}{ccc}
\hline Origin & $\begin{array}{c}\text { Entry name, accession no. } \\
\text { \& evaluation program }\end{array}$ & Entry No. \\
\hline
\end{tabular}

\begin{tabular}{llc}
\multicolumn{2}{c}{ Entries studied for their production under one N level } \\
Bangladesh & IF $2606(\mathrm{E})^{*}$ & 1 \\
ICARDA & IF $1348(\mathrm{E})+(\mathrm{LO})$ & 2 \\
Bangladesh & IF $2096(\mathrm{E})$ & 3 \\
ICARDA & IF $1310(\mathrm{LO})$ & 4 \\
ICARDA & IF $1351(\mathrm{LO})+(\mathrm{E})$ & 5 \\
ICARDA & IF $1346(\mathrm{LO})+(\mathrm{HB})$ & 6 \\
ICARDA & IF $1314(\mathrm{LO})$ & 7 \\
ICARDA & IF $1313(\mathrm{LO})$ & 8 \\
Bangladesh & IF $2329(\mathrm{HB})+(\mathrm{E})$ & 9 \\
Turkey & IF $3(\mathrm{HB})$ & Check1 \\
Check entries & studied under three N fertilization levels \\
Syria & IF 587 & Check2 \\
ICARDA & IF 1322 & Check3 \\
ICARDA & IF 1332 & Check4 \\
ICARDA & IF 1344 & Check5 \\
ICARDA & IF 1347 & \\
\hline
\end{tabular}

*Type of ICARDA evaluation program:

$(\mathrm{E})=$ Early maturing, $(\mathrm{LO})=$ low B-ODAP, $(\mathrm{HB})=$ High biomass

The performance of the 10 entries was studied in a randomized complete plot design experiment with three replicates to evaluate their growth and productivity under one level of nitrogen fertilization $(96 \mathrm{~kg} \mathrm{~N} / \mathrm{ha}$ in the form of ammonium nitrate $33.5 \% \mathrm{~N}$ added in two doses, the first was applied at sowing and the second was applied 30 days later), which is the standard level for legumes grown in the absence of the suitable Rhizobium bacterial species. The second experiment was designed to investigate the effect of nitrogen fertilization on growth and productivity of the five grass pea check entries (Table 1) used by ICARDA for the different yield trials. Because check entries are more stable under various environments, they represented a good set of entries to study the effect of increasing levels of nitrogen fertilization. The entries were grown in a factorial experiment laid out in a randomized complete block design with three replicates with the application of nitrogen levels of 96,144 and $192 \mathrm{~kg}$ $\mathrm{N} /$ ha. Nitrogen fertilizer was applied as ammonium nitrate $33.5 \% \mathrm{~N}$ in split of doses of $48 \mathrm{~kg} \mathrm{~N} /$ ha each. The first dose was applied at sowing for all treatments and later doses followed 30 days apart until the targeted nitrogen amount was achieved.

In both experiments, each entry was assigned two ridges (each $4 \mathrm{~m} \times 0.7 \mathrm{~m}$ ). Two seeds were sown/hill, with hills being $20 \mathrm{~cm}$ apart, on both sides of the ridge. Phosphate fertilizer was applied at the rate of $74 \mathrm{~kg}$ $\mathrm{P}_{2} \mathrm{O}_{5} /$ ha during soil preparation. Surface irrigation was applied five times during the growing season (at sowing, 30, 60, 90 and 120 days afterwards). Sowing was on November the $13^{\text {th }}$ and harvesting was on May the $28^{\text {th }}$ in both growing seasons. The investigated traits were; (a) Soil cover $(\%)$, measured as the soil area covered by plants of an entry as related to the area of the ridge devoted to the entry, and measured at the pod setting stage. (b) Biological yield ( $\mathrm{kg} / \mathrm{ha})$, measured as the dry weight of the above-ground crop mass. (c) Seed yield $(\mathrm{kg} / \mathrm{ha})$, measured as the dry weight of the crop seeds. (d) Harvest index, estimated as the ratio of seed yield to biological yield.

Statistical analysis of data for the experiments was carried out according to Gomez and Gomez (1984). Data for the ten entries were presented in a combined analysis for the two growing seasons due to homogeneity of variance between the years according to Winer (1971). Means of entries, nitrogen levels and their interaction were compared using L.S.D at 0.05 level of probability.

\section{RERSULTS AND DISCUSSION}

\section{(I) Performance of $\mathbf{1 0}$ introduced entries:}

The combined analysis of variance (Table 2) for both seasons revealed insignificant effects for seasonal variations (years) and years $\mathrm{x}$ entries interactions. Similarly, entries showed insignificant variations for all studied traits except biological yield (Table 2). The seasonal variation effects were of much less importance than either the entries or entries $\mathrm{x}$ year interaction. These results were not in harmony with those of Larbi et al. (2010) and Jafari et al. (2013), where significant effects of seasonal variations and season $\mathrm{x}$ genotype were observed. This contradiction in results might be attributed to the differences in the source of irrigation 
water applied in our study (surface irrigation), as opposed to varying annual precipitation received in those studies. The mean values for the studied traits (Table 3) indicated the presence of variability between the studied ten entries, although variation was statistically significant only for biological yield. The highest values for biological yield (2.69 t/ha) and seed yield $(0.65 \mathrm{t} / \mathrm{ha})$ were obtained from the entry IF 1346 from ICARDA. On the other hand, the least values for these traits were obtained from the entry IF 2329 from Bangladesh, (Table 3). A difference in harvest index of $8.81 \%$ was observed between the highest value of $29.77 \%$ from the entry IF 1313 , from ICARDA and the least value of $20.96 \%$ for the entry IF2606 from Bangladesh. It is worth mentioning that the entry IF 1346 characterized by the highest values for biological and seed yield, is a low ODAP entry that is characterized by high biomass from ICARDA (Table 1), suggesting that it is possible to select entries with more than one desired trait. On the other hand, the entries IF 3 and IF 2329, that are also designated as high biomass entries by ICARDA, scored least in biological and seed yield and were collected from Turkey and Bangladesh, respectively. These variations in entry performance could be attributed to the differences in their genetic make-up and their response to the local environmental conditions. These findings were in harmony with the findings of several studies on grass pea (Robertson and Abd El-Moneim 1995, Kardag et al., 2004 and Larbi et al., 2010). Contrary to Jafari et al. (2013), where six grass pea genotypes were evaluated for herbage and seed yield and variability between genotypes was sufficient for selection of promising genotypes for cultivation under rain-fed conditions, our results on 10 entries showed significant variations in biological yield, but insignificant variations for seed yield, making selection for the latter infeasible.

Based on the combined analysis across the two growing seasons presented in this study, the tested grass pea entries produced seed yield within the range of 0.37$0.65 \mathrm{t} / \mathrm{ha}$. These values were on the lower range of the values reported by Kardag et al. (2004) and Jafari et al. (2013). However, seed yield of the tested entries appeared to fit more into the range of 0.029-1.4 t/ha reported by Robertson and Abd El-Moneim (1995). This can be explained by the fact that the latter studied a large number of entries (272 entries) that represented a very broad range of genetic variation as compared to the small selected number of entries tested in this study. This stresses the importance of screening a much larger number of entries with a large genetic background than the ten tested here, before any feasible selection under Egyptian local conditions could be performed.

Table 2. Analysis of variance for soil cover, biological yield, seed yield and harvest index combined over the 2012/2013 and 2013/2014 seasons for the ten studied entries.

\begin{tabular}{lccccc}
\hline s.o.v & d.f. & Soil cover & Biological yield & Seed yield & Harvest index \\
\hline Year & 1 & 6.03 & 0.49 & 0.02 & 1.10 \\
Error a & 2 & 62.49 & 11.72 & 0.65 & 102.88 \\
Entry & 9 & 146.20 & $1.09^{*}$ & 0.05 & 36.22 \\
Year x Entry & 9 & 101.03 & 0.64 & 0.02 & 32.22 \\
Error b & 36 & 132.58 & 0.43 & 0.03 & 22.16 \\
\hline
\end{tabular}

*: significant at 0.05 levels of probability.

Table 3. Mean values for soil cover, biological yield, seed yield and harvest index as affected by entries combined over the two seasons of 2012/2013 and 2013/2014 for the ten studied entries

\begin{tabular}{lcccc}
\hline \multicolumn{1}{c}{ Entries } & Soil cover (\%) & Biological yield (t/ha) & Seed yield (t/ha) & Harvest index (\%) \\
\hline IF 2606 & 67.08 & $2.44 \mathrm{ab}$ & 0.52 & 20.96 \\
IF 1348 & 55.00 & $2.65 \mathrm{a}$ & 0.57 & 21.94 \\
IF 2096 & 59.16 & $1.86 \mathrm{c}$ & 0.46 & 24.06 \\
IF 1310 & 71.66 & $2.37 \mathrm{ab}$ & 0.52 & 22.39 \\
IF 1351 & 59.33 & $2.42 \mathrm{ab}$ & 0.62 & 25.81 \\
IF 1346 & 69.16 & $2.69 \mathrm{a}$ & 0.65 & 24.06 \\
IF 1314 & 75.00 & $2.22 \mathrm{abc}$ & 0.57 & 24.72 \\
IF 1313 & 64.58 & $1.97 \mathrm{abc}$ & 0.56 & 29.77 \\
IF 2329 & 52.50 & $1.54 \mathrm{c}$ & 0.37 & 23.56 \\
IF 3 & 63.58 & $1.62 \mathrm{c}$ & 0.42 & 25.29 \\
L.S.D. & n.s. & 0.77 & n.s. & n.s. \\
\hline
\end{tabular}

Means followed by the same letter (s) in each column are

insignificantly different at 0.05 level of probability.

n.s. : Not significant at 0.05 level of probability. 


\section{(II) Effect of nitrogen fertilization on growth and productivity of five check entries:}

Analysis of variance for the two seasons (Table 4) indicated significant variations due to $\mathrm{N}$ levels with regard to soil cover, biological yield and seed yield in the first season. In the second season however, $\mathrm{N}$ levels showed significant variation for seed yield, while entries and $\mathrm{N}$ levels $\mathrm{x}$ entries showed significant variations for harvest index only (Table 4).

In the first season, the highest level of nitrogen (192 $\mathrm{kg} \mathrm{N} / \mathrm{ha}$ ) gave significantly higher soil cover $(86.8 \%)$, biological yield (6.11 t/ha), and seed yield (1.27 t/ha), these values did not differ significantly from those observed for $144 \mathrm{~kg} \mathrm{~N} /$ ha for biological yield and seed yield (Table 5). The least significant values were obtained for the $96 \mathrm{~kg} \mathrm{~N} /$ ha for all three traits. Harvest index on the other hand, was not affected by the $\mathrm{N}$ levels in either season. These results are in general agreement with those of Sarkar and Malik (2001), where a significant increase in seed yield was observed with foliar application of nitrogen in the form of $\mathrm{Ca}\left(\mathrm{NO}_{3}\right)_{2}$ or $\mathrm{KNO}_{3}$ as compared to the control.

In the second season, $\mathrm{N}$ levels had significant effects only on seed yield, where $192 \mathrm{~kg} \mathrm{~N} /$ ha gave the highest seed yield (0.69 t/ha), which did not differ significantly from $96 \mathrm{~kg} \mathrm{~N} / \mathrm{ha}$. The least significant seed yield was obtained from $144 \mathrm{~kg} \mathrm{~N} /$ ha (Table5). Significant differences between entries and the interaction between nitrogen levels and entries were observed in the second season only for harvest index. The entry IF1347 gave the highest harvest index (14.62) with $96 \mathrm{~kg} \mathrm{~N} /$ ha while the least entry was IF 587 (6.91) with $96 \mathrm{~kg} \mathrm{~N} / \mathrm{ha}$ (Table 5). Simple correlation coefficients between the studied characters for both seasons (data not shown), indicated that only seed yield was significantly and positively correlated with biological yield $r=(0.86)$. Similar correlations between seed yield and biological yield were reported by Jafari et al. (2013). Although our experiments were not designed to statistically compare between the ten entries and the check entries, it is clear that under the same nitrogen level (96 kg N/ha), the check entries performed much better for all studied traits than the ten entries.

The results presented here may be the first to reveal the response of grass pea entries to application of mineral nitrogen fertilizer. Both biological and seed yields were significantly increased with increasing $\mathrm{N}$ application level up to $192 \mathrm{~kg} \mathrm{~N} / \mathrm{ha}$. That may be attributed to the role of nitrogen in promoting vegetative growth of plants and enhancement of assimilates production, resulting in a higher biomass and increased seed setting (Sarkar and Malik, 2001, Fageria, 2009). A highly significant correlation between seed yield and biological yield, in both seasons, further illustrated that vegetative growth, as determined by level of $\mathrm{N}$ application, was a detrimental factor in increasing both herbage and seed yields of grass pea. Results presented here have also indicated that seed yield up to $1.55 \mathrm{t} / \mathrm{ha}$ could be achieved under $192 \mathrm{~kg} \mathrm{~N} / \mathrm{ha}$ under local conditions from the check entry IF 1332. This productivity is already comparable to the national productivity in Nepal (1.2 t/ha) according to MOAC (2013) and the national productivity of Ethiopia (1.8 $\mathrm{t} / \mathrm{ha}$ ) under mineral fertilization conditions, while was four times the productivity $(0.4 \mathrm{t} / \mathrm{ha})$ with no mineral fertilization (CSA 2014). Despite these results, performance of grass pea under irrigated conditions in Alexandria, Egypt, was not very promising. Extremely high levels of nitrogen fertilization were required to approach levels of production observed in Ethiopia, where mineral fertilization is generally scarce and irrigation is rain-dependent. Furthermore, the susceptibility of grass pea to infestation with Orobanche crenata, observed in some spots in the experiments of $2013 / 2014$, suggest that complete loss of the crop may occur if grown in areas where the parasite seeds are abundant. Thus it could be concluded that the studied entries were not best suited to our local conditions. The genetic constitution of entries and its interaction with environmental conditions governs the expression of measured traits.

Table 4. Analysis of variance for soil cover, biological yield, seed yield and harvest index during $2012 \backslash 2013$ and 2013/2104 growing seasons for the five check entries

\begin{tabular}{lccccccccc}
\hline & & \multicolumn{2}{c}{ Soil cover } & \multicolumn{2}{c}{ Biological yield } & \multicolumn{2}{c}{ Seed yield } & \multicolumn{2}{c}{ Harvest index } \\
\cline { 2 - 10 } s.o.v & d.f. & S1 & S2 & S1 & S2 & S1 & S2 & S1 & S2 \\
\hline N levels & 2 & $932.67^{* *}$ & 565.70 & $27.83^{* *}$ & 14.20 & $0.75^{* *}$ & $0.21^{*}$ & 37.71 & 6.92 \\
Entries & 4 & 84.93 & 200.13 & 4.46 & 2.20 & 0.17 & 0.09 & 14.82 & $22.70^{* *}$ \\
N level x Entries & 8 & 16.24 & 66.97 & 3.02 & 3.37 & 0.07 & 0.10 & 18.18 & $6.09^{*}$ \\
Error & 28 & 45.05 & 370.84 & 2.85 & 4.73 & 0.09 & 0.05 & 19.78 & 2.36 \\
\hline
\end{tabular}

S1: 2012/2013 growing season. S2: 2013/2104 growing season.

${ }^{*}, * *$ : significant at 0.05 and 0.01 levels of probability, respectively. 
Table 5. Means of soil cover, biological yield, seed yield and harvest index as influenced by grass pea entry and nitrogen levels during seasons $2012 \backslash 2013$ and 2013/2014 for the five check entries

\begin{tabular}{|c|c|c|c|c|c|c|c|c|c|}
\hline \multirow[t]{2}{*}{$\begin{array}{c}\text { Nitrogen } \\
\text { levels }\end{array}$} & \multirow[t]{2}{*}{ Entry } & \multicolumn{2}{|c|}{$\begin{array}{c}\text { Soil cover } \\
(\%)\end{array}$} & \multicolumn{2}{|c|}{$\begin{array}{c}\text { Biological yield } \\
\text { (t/ha) }\end{array}$} & \multicolumn{2}{|c|}{$\begin{array}{c}\text { Seed yield } \\
(\mathrm{t} / \mathrm{ha})\end{array}$} & \multicolumn{2}{|c|}{$\begin{array}{c}\text { Harvest index } \\
(\%)\end{array}$} \\
\hline & & S1 & S2 & S1 & S2 & S1 & S2 & S1 & S2 \\
\hline \multirow{6}{*}{$\begin{array}{c}96 \\
\mathrm{~kg} \mathrm{~N} / \mathrm{ha}\end{array}$} & IF 587 & 66.66 & 90.00 & 3.27 & 7.43 & 0.89 & 0.51 & 27.0 & $6.91 \mathrm{~d}$ \\
\hline & IF 1322 & 72.50 & 66.67 & 3.89 & 6.52 & 1.15 & 0.51 & 29.54 & $7.97 \mathrm{~cd}$ \\
\hline & IF 1332 & 73.33 & 64.33 & 4.04 & 7.13 & 0.87 & 0.75 & 22.65 & $10.50 \mathrm{bc}$ \\
\hline & IF 1344 & 63.33 & 66.67 & 3.06 & 6.52 & 0.78 & 0.50 & 25.24 & $7.74 \mathrm{~cd}$ \\
\hline & IF 1347 & 55.83 & 75.00 & 2.84 & 7.54 & 0.67 & 1.10 & 23.41 & $14.62 \mathrm{a}$ \\
\hline & Mean & $66.3 \mathrm{c}$ & 72.53 & $3.42 \mathrm{~b}$ & 7.03 & $0.87 \mathrm{~b}$ & $0.68 \mathrm{a}$ & 25.57 & 9.55 \\
\hline \multirow{6}{*}{$\begin{array}{c}144 \\
\mathrm{~kg} \mathrm{~N} / \mathrm{ha}\end{array}$} & IF 587 & 70.42 & 66.67 & 4.24 & 4.55 & 1.10 & 0.40 & 26.05 & $7.99 \mathrm{~cd}$ \\
\hline & IF 1322 & 79.83 & 56.67 & 5.53 & 7.66 & 1.35 & 0.73 & 24.37 & $9.31 \mathrm{bcd}$ \\
\hline & IF 1332 & 72.50 & 62.67 & 5.36 & 4.40 & 1.23 & 0.39 & 23.61 & $8.99 \mathrm{bcd}$ \\
\hline & IF 1344 & 74.83 & 53.33 & 5.37 & 5.04 & 1.41 & 0.37 & 25.86 & $7.30 \mathrm{~cd}$ \\
\hline & IF 1347 & 69.58 & 63.33 & 5.17 & 4.05 & 1.14 & 0.50 & 22.15 & $9.94 b c$ \\
\hline & Mean & $73.4 \mathrm{~b}$ & 60.53 & $5.13 \mathrm{a}$ & 5.14 & $1.25 \mathrm{a}$ & $0.48 \mathrm{~b}$ & 24.41 & 8.70 \\
\hline \multirow{6}{*}{$\begin{array}{c}192 \\
\mathrm{~kg} \mathrm{~N} / \mathrm{ha}\end{array}$} & IF 587 & 87.33 & 85.00 & 5.42 & 6.79 & 1.22 & 0.62 & 23.38 & $8.99 \mathrm{bcd}$ \\
\hline & IF 1322 & 88.33 & 80.00 & 5.56 & 6.69 & 1.24 & 0.72 & 22.84 & $10.25 \mathrm{bc}$ \\
\hline & IF 1332 & 92.67 & 92.50 & 6.73 & 7.29 & 1.55 & 0.83 & 23.02 & $10.22 b c$ \\
\hline & IF 1344 & 85.67 & 63.33 & 8.71 & 6.61 & 1.42 & 0.65 & 18.05 & $9.59 \mathrm{bcd}$ \\
\hline & IF 1347 & 80.33 & 80.00 & 4.13 & 5.16 & 0.94 & 0.62 & 24.88 & $11.18 \mathrm{~b}$ \\
\hline & Mean & $86.8 \mathrm{a}$ & 80.17 & $6.11 \mathrm{a}$ & 6.51 & $1.27 \mathrm{a}$ & $0.69 \mathrm{a}$ & 22.43 & 10.05 \\
\hline \multicolumn{2}{|c|}{ L.S.D. } & n.s. & n.s. & n.s. & n.s. & n.s. & n.s. & n.s. & 2.57 \\
\hline
\end{tabular}

S1: 2012/2013 growing season.

S2: 2013/2014 growing season.

n.s.: Not significant at 0.05 level of probability.

* Means followed by the same letter (s) in each column are insignificantly different at 0.05 level of probability.

In quantitative traits such as biomass production and seed yield, environmental effects may be of high magnitude to mask the genetic differences between entries, as revealed by the results obtained from the present study. To elucidate such differences, more entries should be tested across a wide range of environmental conditions in comparison to the check entries studied here before suitable entries could be selected under Egyptian conditions.

\section{REFERENCES}

Abd El-Moneim, M. and J.Ryan. 2004. Forage legumes for dryland agriculture in Central and West Asia and North Africa. In: Rao, S.C., Ryan, J. (Eds.), Challenges and Strategies for Dryland Agriculture. CSSA Special Publication 32. Crop Science Society of America, American Society of Agronomy, Madison, WI, USA, pp. 243-256.

CSA. 2014. Agricultural Sample Survey (2012-2013). Report on area and production of crops. Central Statistical Agency. Addis Ababa, Ethiopia.

El-Nahrawy, M.A. 2011. Country pasture/forage resource profiles. Food and Agriculture Organization of the United Nations (FAO), 2011.
Fageria, N.K. 2009. The use of nutrients in crop plants p. 3176. CRC press, Taylor and Francis Group, New York, USA.

Gomez, K.A., Gomez, A.A. (1984). Statistical procedures for agricultural research $\left(2^{\text {nd }}\right.$ ed.). John Wiley and Sons. New York.

Hanbury, C.D., C.L.White, B.P. Mullan, and K.H.M.Siddique. 2000. A review of the potential of Lathyrus sativus L. and L. cicera L. grain for use as animal feed. Anim. Feed Sci. Tech. 87 (1-2): 1-27.

Jafari, A.A, P.M.Godarzi, S. Nakhjavan, and M.Cheshmehnoor. 2013. Herbage and seed production of two Species of Lathyrus L. under rainfed condition of Borujerd. Iran. J. Rangeland Sci. 3(2): 155-164.

Kardag, Y., S.Iptas, and M.Yavuz. 2004. Agronomic potential of grass pea (Lathyrus sativus L.) under rainfed condition in semi-arid regions of Turkey. Asian J. Plant Sci. 3(2): 151-155.

Larbi, A., S.Hassan, G.Kattash, A.M.Abd El-Moneim, B.Jammal, H.Nabil, and H.Nakkul. 2010. Annual feed legume yield and quality in dryland environments in north-west Syria: 1. Herbage yield and quality. Anim. Feed Sci. Tech. 160: 81-89. 
MOAC. 2013. Statistical information on Nepalese agriculture, 2012/2013. Ministry of agriculture and cooperatives (MOAC), Agri-business promotion and statistics division, Singha Durbar, Kathmandu, Nepal.

Montenegro, A.A., and M.M.Mera. 2009. Phosphate fertilization can increase yield of productive grass pea (Lathyrus sativus L.) crops in P-retentive soils. Chilean J. Agr. Res. 69(2): 244-251.

Petritz, D.C., V.L. Lechtenberg, and W.H. Smith. 1980. Performance and economic returns of beef-cows and calves grazing grass-legume herbage. Agron. J. 72: 581584.

Robertson, L.D. and A.M. Abd El-Moneim. 1995. Lathyrus germplasm collection, conservation and utilization for crop improvement at ICARDA. In: R.K.Arora, P.N.Mathur, K. W.Riley, and Y.Adham. (Eds.) Lathyrus genetic resources in Asia. Proceedings of a regional workshop, 27-29 December 1995, Indira Gandhi Agricultural University, Raipur, India, pp. 97-111. IPGRI office for South Asia, New Delhi, India.
Salama, H.S.A., and M.M.Zeid.2017. Fodder Beet (Beta Vulgaris L.) Yield and Quality Attributes as Affected by Sowing Date, Age at Harvest and Boron Application.Alex.Sci.Exch.J.38(1):1-12

Sarkar, R.K. and G.C. Malik. 2001. Effect of foliar spray of potassium nitrate and calcium nitrate on grass pea (Lathyrus sativus L.) grown in rice fallows. Lathyrus lathyrism Newsl. 2: 47-48.

Sarkar, R.K., B.Biswas, and G.C. Malik. 2003. Productivity of grass pea (Lathyrus sativus L.) under different levels of phosphorus and foliar spray of molybdenum. Lathyrus lathyrism Newsl. 3: 36-37.

Winer B.J. 1971. Statistical principles in experimental design. $2^{\text {nd }}$ Edition. McGraw-Hill Kogakusha, LTD. 


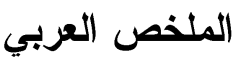

تقييم بعض السلالات المستورده من الجلبان وتأثير معدلات التسميد النيتروجينى على إنتاجية عدد منها

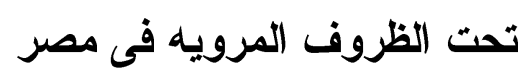

أحمد محمود السيد، على عبسى نوار ومحمود محمد زيد

الثانية فقد أجريت بنفس خطو ات التجربة السابقة ولكـن إستخدم فيها خمس سلالات أخرى وهى سلالات تستخدمها الإيكاردا كسلالات للمقارنة عند تقييم السلالات المختلفة وتم

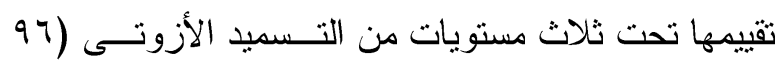

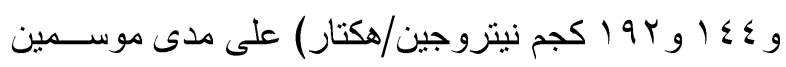
لادراسة تأثير مستويات النيتروجين على نموها و إنتاجيتهــا.

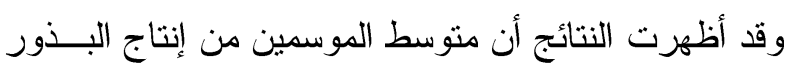

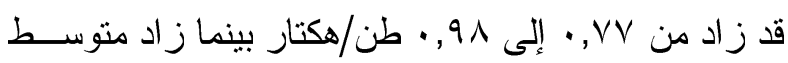

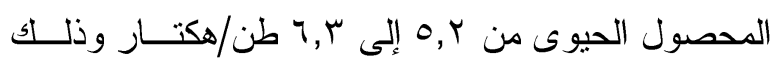

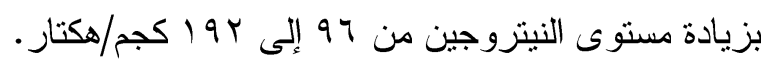

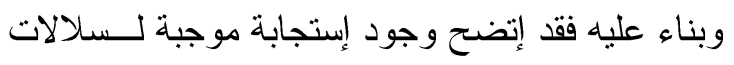

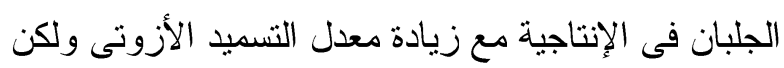

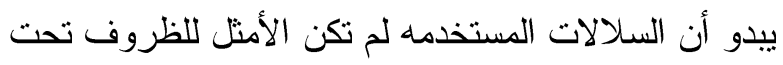

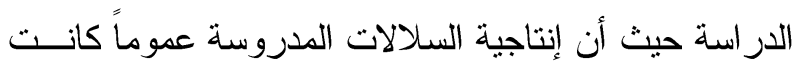
منخفضة مقارنه بإنتاجية دول أخرى تقوم بزر اعة الجلبـان

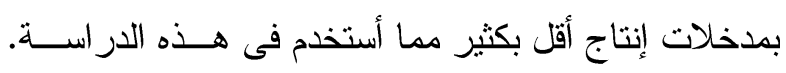
ولعل ذلك يشير إلى ضرورة تقييم عدد أكبر من الـسلالات تحت ظروف بيئية مختلفة للوصول إلى سلاله عالية الإنتاج حتى تحت ظروف أقل ملائمة من تلك تحت الدر اسة.
حَظى الجلبان (Lathyrus sativus L.) وهــو محسـصول

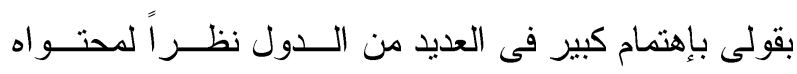
العالى من البروتين وتحمله للظروف البيئية الصعبة. و تعد نظرية إستخدام بذوره و الدريس الناتج منه فى موسم الثتاء بعد التجفيف و الحفظ لرفع قيمة الأعلاف النجيلية الــصيفية منخفضة البروتين هى نظرية مطروحه منذ عشرات السنين

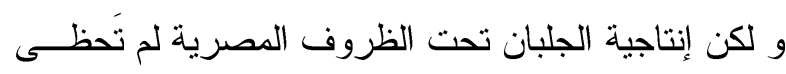
بالقدر الكافى من الدراسه لإختبار تلكك النظرية.

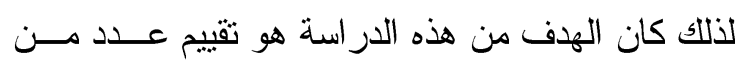
السلالات المستوردة من الجلبان و كـــللك دراســة تــأثير

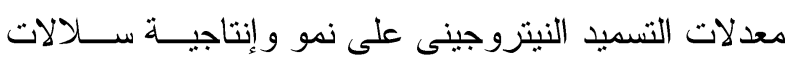
محدده من الجلبان تحت الظروف المرويه فى الأسكندريه.

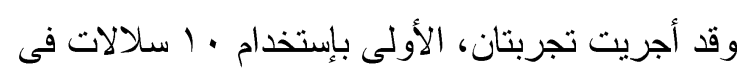

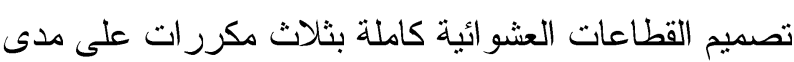

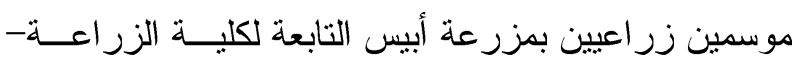

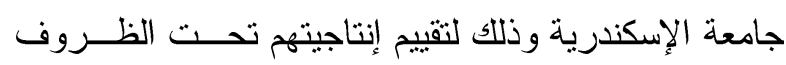

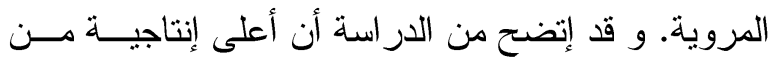

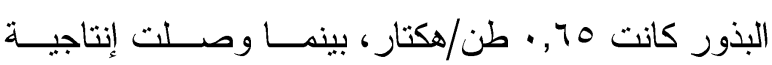

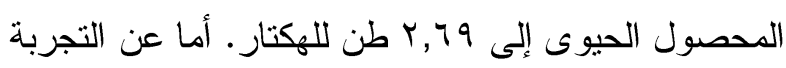

